\title{
The Bible and Musical Postmodernism
}

\author{
Sorana MĂNĂILESCU ${ }^{1}$
}

\begin{abstract}
The paper examines formal changes of traditional church music in postmodernism: the choice of brief passages in the Bible characterised by soul searching (Jesus musing on his destiny, experiencing confusion about his purpose and mission), heroic acts (Esther and Judith saving the Jewish people), self-sacrifice and moral fables rather than key chapters of dogmatic stringency. Characteristic of postmodernist aesthetics are the combination of high and low art, fragmentation, and hybridity. Music rooted in the Bible draws on heterogeneous sources, such as medieval religious mysteries (the Wakefield Mysteries), jazz, folk music (Celtic, Far Eastern or East European, as in James MacMillan's Seven Last Words from the Cross, 1994) quasi ancient music (actually a pastiche, as in Howard Goodall's The Beautitudes, 2009). The sacramental atmosphere is lost in a narrative about a tamed and belittled Jesus figure: The Boy (1977) by David Palmer, or El Niňo (2000) by John Adams. These compositions at the turn of the millennium are belated and sublimated echoes of the rock operas of the '70s, which carried with them intimations of politics (as in Yale Marshall's The Business of Good Government, 1970), disseminating concern for the public spirit, care for the wretched of the earth, support for the hippie movement and ideology (especially Lloyd-Weber's Jesus Christ Superstar).
\end{abstract}

Key-words: Postmodernism, Bible, hybridity, intertextuality, rhizome

\section{Introduction}

The radical changes in the musical compositions drawing on the Bible in late modernity (modernism and postmodernism) bear testimony to the fact that thematic content counts less than the generic conventions, cultural tendencies, procedures and attitudes characterising each phase in the history of music. Never before had composers been aware of the mutual influences among the discourses of an age as they were in the postwar period, commonly referred to as postmodernism. Heterogeneity, collage techniques and fragmentation had also characterised the earlier half of the century, but this time they concern, not only

${ }^{1}$ Transilvania University of Braşov, soranatupan@yahoo.com 
various art forms, but distinct disciplinary fields. On February 23, 2017 Washington Post noted in connection with Grammy nominee Christopher Theofanidis: "What impresses me about Theofanidis is his ability to blend several musical languages once thought to be mutually exclusive (...) there are elements of Asian music, minimalism, high chromaticism, and a sort of brightly colored impressionism (...) the results are enormously attractive." (music.depauw.edu 2017: web). The performance of Theofanidis's oratorio for soloists, chorus and orchestra, Creation/ Creator in 1915 by Atlanta Symphonic Orchestra conducted by Robert Spano exposed the audience to a mix of references from mythology (Rig Veda, the Jewish Genesis, a Chinese myth of Creation), philosophy (Plato, Aristotle, Leibniz), literature (Chaucer, Dante, Herman Melville, Walt Whitman, Truman Capote, Margaret Cavendish), art (Michelangelo), science (from ancient Democritus to contemporary relativism - Einstein - or quantum physics - Planck).

Unlike modernist aesthetic programmes, which focused on musical structure and expression, is also the attempt to define the new music in relation to contemporary philosophy, especially deconstructionist Derrida, analytic philosopher Gilles Deleuze, and theoreticians of the postmodernist canon (Ihab Hassan and Jean-François Lyotard). Derrida's idea of music as spectral, haunted by other composers' works or texts (Cobussen 2012: web), the return to cultural contexts instead of focus on form identical to itself was favourable to a return to myth as well.

We are following in the same track trying to identify a common stylistic matrix for domains as different as music and physics in discussing modernism and music and linguistics in relation to postmodernism, as the earlier half of the century was dominated by the New Physics, whereas the postwar period has been dominated by linguistic models.

The method we have adopted is interdisciplinary in answer to the polyvalent (postformal) logic of the articulation of the musical idiom, that is, our explanatory narrative about postmodernist canonization is working across divisions, such as science and humanities, as well as music and the rest of contemporary art forms.

The aim of this paper is to bring up arguments supporting a Foucauldian view of all the idioms of an age being underwritten by a common episteme. Although the Bible has pooled over time a huge amount of musical compositions, common features between Haydn's The Creation oratorio on one hand, and the pieces of music going under the same heading signed by Antonio Braga (San Domenico di Guzman, 1997), Matthew King (Gethsemane chamber oratorio, 1998), John Adams (El Niňo opera-oratorio, 2000), or Christopher Theofanidis (Creation/ Creator, oratorio, 2015), etc. on the other are hard to find. 


\section{The Language of Modernism: Structure and Function}

The earlier half of the twentieth century came under the influence of Saussure's structuralism and of functionalism. The former reduced language to formal differences within a sign system indifferent to a referential world of outward meanings, teleological acts or intentional subjectivity. Structure emerged out of binary oppositions, combinations and permutations of signs. As for functionalism, it gave up on the identity theory of mind focusing on sensory impressions or chance associations triggered by the unconscious. Here is Arnold Schoenberg's confession in a letter to Ferruccio Busoni, dated August 1909 in which he defends his athematism:

"I strive for: complete liberation of all forms from all symbols of cohesion and of logic. Thus: away with 'motivic working out'. Away with harmony as cement or bricks of a building. Harmony is expression and nothing else.[...]:Concise! In two notes, not built but 'expressed'!! [...]

And this variegation, this multifariousness, this illogicality which our senses demonstrate, the illogicality presented by their interactions, set forth by some mounting rush of blood, by some reaction of the sense or the nerves, this I should like to have in my music. It should be an expression of feeling, as our feelings, which bring us in contact with our subconscious, really are, and no false child of feelings and 'conscious logic.' [...] My only intention is to have no intentions!" (Schoenberg 2003, 70)

On writing this, Schönberg was probably still in the mind which had recently completed The Book of Hanging Gardens (February of 1909), set to lyrics by Stefan George - an adept of art for art's sake (formal expression that is its own end). Jack F. Boss considers that Schönberg's early compositions are still displaying "overarching formal, harmonic, rhythmic or motivic patterns [...]. networks of motivic and harmonic relationships." (Boss 2015: Structural iterativity, however, repetitions and returns may very well be disconnected from the constant association with a certain meaning, as they are in Wagner. They are just patterned language governed by chance associations triggered by unconscious drives. Meaning does not originate in reference but in differences among words/ sounds. We notice, for instance, the motivic alternation, repetition and extension in Schoenberg's Op. 15 no 7, in which the Stefan George lyrics vacillate between "Angst und hoffen": 
Angst und hoffen wechselnd mich beklemmen,

Meine worte sich in seufzer dehnen,

Mich bedrängt so ungestümes sehnen,

Dass ich mich an rast und schlaf nicht kehre,

Dass mein lager tränen schwemmen,

Dass ich jede freude von mir wehre,

Dass ich keines freundes trost begehre. ${ }^{2}$

The 7-8-9-10-11 range of measures in the top piano line are similar in the imitation of the rising-falling pattern corresponding to the contraction/ expansion of the sighing body, even if there is an inner opposition between contradictory feelings such as anxiety and hope. They both merge into the heaving breast motive of measure 9 extended in measures 10 and eleven (Figure 1).

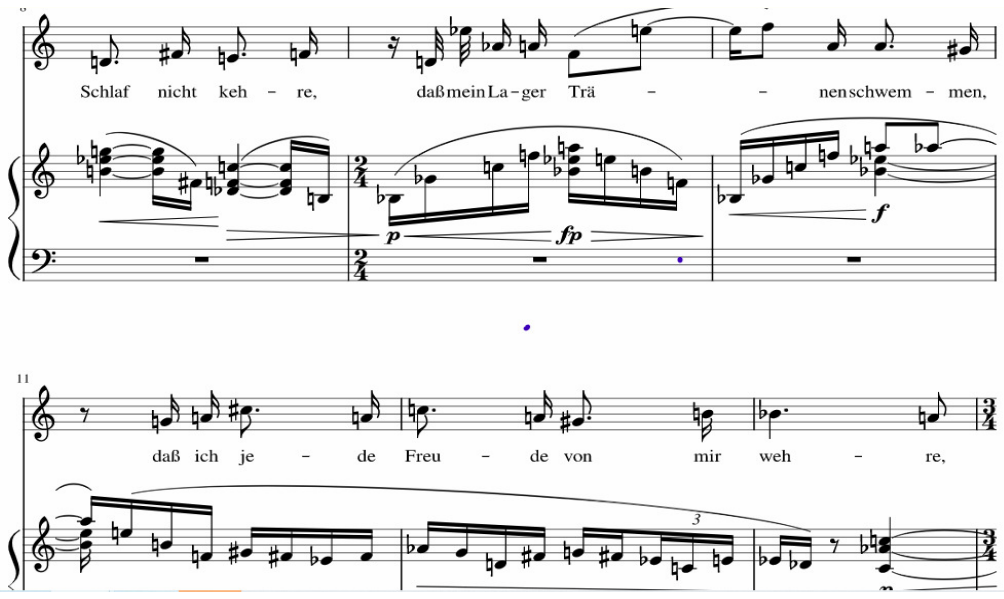

Fig. 1. Arnold Schoenberg's Op. 15 no 7, measures 7-12.

Composer Ermir Bejo undertakes a Set-Class analysis of the piano part of Schönberg's Op.15, no.1. (Figure 1) meant to reveal a structural coherence collecting from a set of repetitions and transpositions (Figure 2). (Bejo 2018: web)

\footnotetext{
${ }^{2}$ Fear and hope alternately oppress me,/ My words stretch into sighs/Longing so impetuously troubles me,/That I rest and sleep,/ That tears flood my bed/ That I repudiate all joy from myself,/ That I do not seek consolation from a friend.
} 

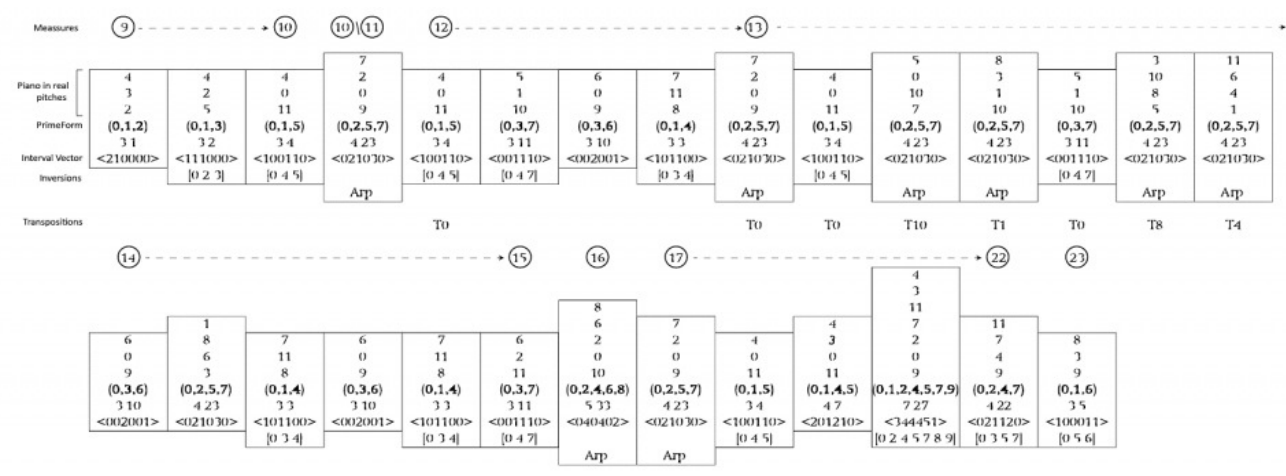

Fig. 2. Pitch-class analysis of the piano part of Schoenberg's Op.15, no.1. 17

1909, the year of Schönberg's The Book of Hanging Gardens, was also an important landmark in 20th century science for the first configuration of a fractal based on self-similarity which took a definite form in Benoit Mandelbrot's equations and transpositions (Figures 3 and 4).

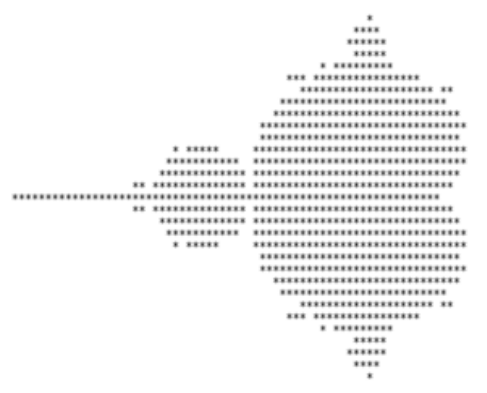

Fig. 3. The first published picture of the Mandelbrot

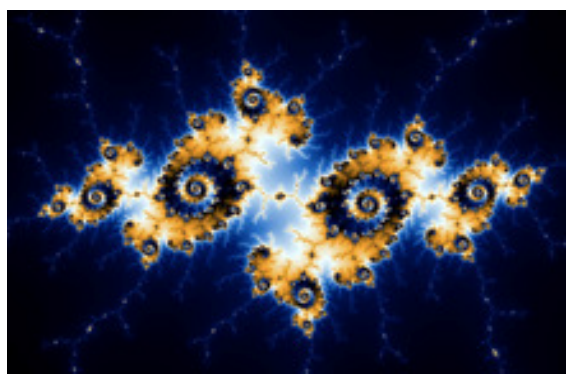

Fig. 4. The Mandelbrot set detail

set by Robert W. Brooks and Peter Matelski in 1978

The idea had been hatched since the beginning of the century. The Book of Suspended Gardens appeared three years after Pierre Fatou's first article on a generative function of homomorphic mathematical objects (Julia 1918, 5) to be studied and named fractals by mathematician Benoit Mandelbrot (Fractals: Form, Chance and Dimension, 1977). Instead of describing a shape or structure, the focus shifted to the principle of its generation. Interestingly, Gaston Julia, one more predecessor to Mandelbrot, was both a mathematician and a musician (Julia 1918, 5). Permutations of a limited number of sounds allowed Schönberg to create a 
musical counterpart to fractal self-similarity. The study of the iteration of a rational fraction $(z 1=\phi(z))$ and the iteration of the sounds of a harmonic range with equal values were both related to the mathematical aloofness of mental arithmetic, supporting the athematic and anti-programmatic agenda of the Second Viennese School of dodecaphonic experimenters. The generation of the fractal set and of dodecaphonic composition are both based on conditioned repetitions and permutations (Figure 5, Figure 6):

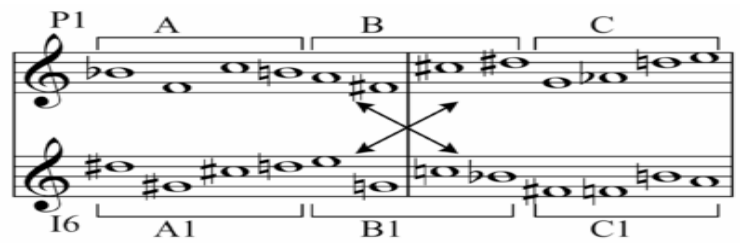

Fig. 5. Schoenberg's twelve-note technique (proliferation of cells)

$$
Z_{n+1}=Z_{n}{ }^{2}+C
$$

What happens to $\mathbf{Z}$ for all the different starting points $\mathbf{C}$ in the complex plane? Normally, we start with $\mathbf{Z}=\mathbf{0}$, so the iterations look like:

$$
\begin{aligned}
& \mathrm{Z}_{1}=\mathrm{Z}_{0}{ }^{2}+\mathrm{C}=\mathrm{C} \\
& \mathrm{Z}_{2}=\mathrm{Z}_{1}{ }^{2}+\mathrm{C}=\mathrm{C}^{2}+\mathrm{C} \\
& \mathrm{Z}_{3}=\mathrm{Z}_{2}{ }^{2}+\mathrm{C}=\left(\mathrm{C}^{2}+\mathrm{C}\right)^{2}+\mathrm{C}
\end{aligned}
$$

Fig. 6. Generation of the Mandelbrot set

\section{The Postmodernist Revolution}

Whereas the beautiful and orderly fractal configuration can serve as simulation model of modernism's formal experimentation, the image serving as simulation model to postmodernism is the rhizome (Figure 7). In A Thousand Plateaus (1980), Gilles Deleuze and Félix Guattari employ this shapeless, protruding, proliferating image of an aerial root, sprawling in all directions ${ }^{3}$, to illustrate the heterogeneous, ungoverned simulation model shared by postmodernist thought, whether the topic be the holistic superposition of world and representation, of the pole of creation and that of reception, the merging of high and popular culture, the transgression of disciplinary borders, etc. Theorist-composer Jonathan D. Kramer compiled an

\footnotetext{
${ }^{3}$ Rhizoma (Euphorbia antiquorum). Wikipedia. https://en.wikipedia.org/wiki/Rhizome
} 
appropriate typology of Postmodern Music, Postmodern Listening for a bipolar meaning maker: the composer and the audience.

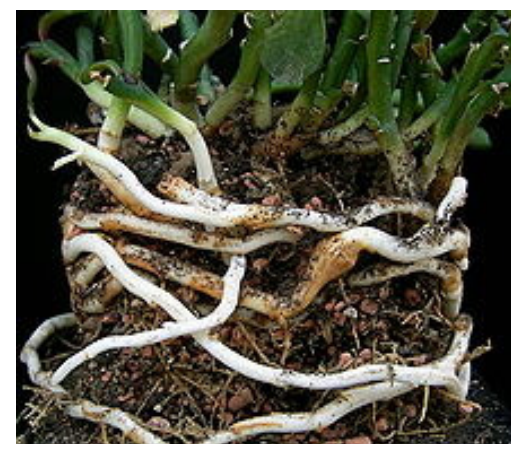

Fig. 7. Simulation model to postmodernism

Claus-Steffen Mahnkopf insists on self-description or self-reflexivity, his own compositions offering plenty of examples of metamusic and intertextuality (Coulembier and Janssens 2017, 18-37), especially in the Kurtág-Zyklus, which includes references to his own compositions, to other composers, as well as literary references, such as Borges and Nietzsche. His 2011 typology of contemporary music ("Musical Modernity from Classical Modernity up to the Second Modernity Provisional Considerations") is probably the most comprehensive one, as it sums up morphological, attitudinal, stylistic, hierarchical, etc. traits.

A single characterization of postmodernism, however, will not do, as there is a considerable difference between the populist tendencies of the 60's and '70s the elitist turn on either side of the new millennium.

Postmodernist music rooted in the Bible draws on heterogeneous sources, such as medieval religious mysteries (the Wakefield Mysteries), jazz, folk music (Celtic, Far Eastern or East European, as in James MacMillan's Seven Last Words from the Cross, 1994) quasi ancient music (actually a pastiche, as in Howard Goodall's The Beautitudes (2009). The sacramental atmosphere is lost in a narrative about a tamed and belittled Jesus figure: The Boy (1977) by David Palmer or El Niňo (2000) by John Adams. These compositions at the turn of the millennium are belated and sublimated echoes of the rock opera of the '70s, which carried with them intimations of politics (as in Yale Marshall, The Business of Good Government, 1970), disseminating concern for the public spirit, care for the wretched of the earth, support for the hippie movement and ideology (especially Lloyd-Weber's Jesus Christ Superstar). Andrew Lloyd-Webber's Joseph and the Amazing Technicolour Dreamcoat (19698) meant a breakthrough at the time of its 
performance at St Paul's Cathedral in 1968, with David Daltrey of the British psychedelic band Tales of Justine playing Joseph. A 15-minute pop oratorio (extended later to 35 minutes) or pop cantata for children, this piece of music thrived upon the eclecticism which had characterised the happening art of the previous decade in America: it combined medieval religious tradition - the Wakefield mysteries, robbed of their religious solemnity by the mix of popular music (rock, cabaret, folk song).

In his PhD. thesis, Fearless Programming: Invigorating the American Orchestral Tradition Through New Music (2016), Octavio Más-Arocas comments on the elitist turn which was mainly effected by the Atlanta Symphony Orchestra and the audience whose standards they managed to raise to new expectations:

"This musical amalgam, the deep ambivalence between serious and popular music, the free-for-all musical offering, was not meant to last. It was those same musicians who formed the first orchestras and men such as Urelli Corelli Hill, Hans Balatka, John Sullivan Dwight, Leopold Damrosch, and Theodore Thomas, who proclaimed the need to deepen the connection between high and low musical cultures. These artists took upon themselves the 'sacralization' of music in America, the enlightenment of the classical music audience, and the elevation of a serious and erudite musical art from the banal and popular music that served as simply entertainment and amusement for all classes." (Más-Arocas 2016, 8).

Christopher Theofanidis is an eclectic and erudite personality, aligning himself with postmodernist composers such as Louis Andriessen, Philip Glass, Arvo Pärt, James MacMillan, John Adams, who broadened the sphere of spiritual music, creating new contexts for "The Great Code", as Northrop Frye appropriately defined the Bible (The Bible and Literature, a study of the mythology and structure of the Bible, published in 1982).

Christopher Theofanidis opens his masterpiece, Creation/Creator, with the Hindu myth of the elephant out of which the universe was born, creating thereof his own parable. In a homorhythmic text declamation, singular voices claim that they have touched some part or other of the elephant's body, for human beings are limited in their knowledge of the world, but by coming together and aligning their views, they are heading for the whole picture that can never be attained, the composer avoiding metanarratives, totalitarian myths. On the contrary, the figure of the confused Creator, lost in the labyrinth of his own creation, the listeners discovering in a piece of music meanings the composer is unaware of, the alienation of the self in one's own creation, the extremely heterogeneous historical 
party crossing spatial, temporal borders, bringing together Dante and protofeminist Margaret Cavendish, Leibniz and Truman Capote, Dante and disciplinary borders, St. Augustine and the Harlem Renaissance, etc. are all steps towards that Book which is believed to contain the ark of humanity's heritage.

\section{Conclusions}

Our research of postmodernist music of Biblical inspiration has proved rewarding in the sense that this chapter of contemporary art contains in little the whole picture of the period: the completion of hybridization started in the earlier half of the last century both in point of content (mix of European and non-European myths, religions) and form (the compositions bearing generic titles inherited from the classical age - oratorio, missa, sacred drama - assimilate musical matter from other ages, such as medieval religious drama), spaces (far-Eastern mythology), register (pop art), generic forms (jazz, negro spiritual, folk music, Asian religious music etc.). At the same time, the latest re-sacralisation of music, surprisingly located in America (the homeland of pop culture) pitches very high the standards of content and performance through erudite borrowings from all the cultures of the world and through formal sophistication.

\section{Acknowledgement}

A grateful thought goes to Ph.D. physicist Marin Cilea who helped us steer our course through the special field of fractal geometry and generation.

\section{References}

Barthes, Roland. 1959. Mythologies. London: Vintage.

Bejo, Ermir. 2018. Postmodernism in Philosophy and Music. https://ermirbejo.com/postmodernism-in-philosophy-and-music

Boss, Jack F. 2015. "Away with Motivic Working?" Not So Fast: Motivic Processes in Schoenberg's op. 11, no. 3, MTO. Journal of the Society for Music Theory, Vol. 21 (3) September. DOI:10.30535/mto.21.3.2 https://mtosmt.org/issues/mto.15.21.3/mto.15.21.3.boss.html\#FN11REF

Cobussen, Marcel. 2002. "Deconstruction in Music. The Jacques Derrida - Gerd Zacher Encounter". In Specters of Bach' in my „interactive" ed. by Cobussen Marcel, 1-9. Rotterdam: Netherlands. https://cobussenma.files. wordpress.com/2011/10/derrida_zacher_encounter.pdf

Connor, Steven. 1989. Postmodernist Culture: Introduction to the Theories of the Contemporary. Oxford: Blackwell Publishers. 
Coulembier, Klaas and Daan Janssens. 2017. "Writing Music (and Music History): Referential Ramifications in Claus-Steffen Mahnkopf's Kurtág-Zyklus." Tempo 71(279): 18-37. doi:10.1017/S0040298216000681.

Deleuze, Gilles and Felix Guattari. 1980. A Thousand Plateaus. Translation by Brian Massumi. Minneapolis / London: University of Minnesota Press .

Derrida, Jacques. 1993. Spectres de Marx: l'état de la dette, le travail du deuil et la nouvelle Internationale. Paris: Éditions Galileé.

Gresham, Mark. 2015. World premiere of Theofanidis' oratorio shows ASO, Spano at the Peak of Power. ArtsATL https://web.archive.org/web/ 20160215215956/http://www.artsatl.com/2015/04/review-world-premieretheofanidis-oratorio-shows-aso-spano-peak-power/

Hassan, Ihab Habib. 1987. The Postmodern Turn: Essays in Postmodern Theory and Culture. Columbus: Ohio State University Press. Available on PhilArchive: https://philarchive.org/archive/HASTPT

Julia, Gaston Maurice. 2001 [1918]. "Mémoire sur I' itération des fonction rationnelles. " Journal de Mathématiques pures et appliquées - 4th tome, 1918. Paris: Gauthier-Villars. Translated by Alessandro Rosa. http://www.math.nsysu.edu.tw/ amen/posters/poster0171.pdf

Kramer, Jonathan D. 2016. Postmodern Music, Postmodern Listening. New York / London/ New Delhi: Bloomsbury Academic.

Letellier, Robert Ignatius. 2017. The Bible in Music. Newcastle upon Tyne: Cambridge Scholars Publishing.

Lyotard, Jean-François. 1979. La condition postmoderne. Paris: Les Éditions de Minuit.

Mahnkopf, Claus- Steffen. Musical Modernity. From Classical Modernity up to the Second Modernity - Provisional Considerations. Web: https://www.yumpu.com/en/document/view/6774443/musical-modernityfrom-classical-modernity-up-to-the-second-

Más-Arocas, Octavio. 2016. Fearless Programming: Invigorating the American Orchestral Tradition through New Music. Bowling Green State University.

Schoenberg, Arnold. 2003. "Two Letters to Ferruccio Busoni, August 1909." In A Schoenberg Reader: Documents of a Life, ed. by Joseph Auner, 13-19. Yale University Press.

Young, Andrew. 2015. Atlanta Symphony Orchestra premieres Creation/Creator: A piece by Christopher Theofanidis explores mankind's genesis. Atlanta.

XXX. 2017. Music of the 21st Century' Brings Grammy Nominee Christopher Theofanidis to Depauw. February 23, 2017. https://www.depauw.edu/newsmedia/latest-news/details/32895/ 